\title{
Харламова Т.В.
}

\section{Коммуникативные стратегии недооценки и переоценки в речи персонажей романа Софи Кинселлы «Шопоголик на Манхэттене»}

Одиниовский филиал МГИМО МИД России

(Россия, Одиниово)

doi: 10.18411/lj-05-2021-283

\section{Аннотация}

В статье рассматриваются коммуникативные стратегии недооценки и переоценки в речи персонажей современного художественного произведения «Шопоголик на Манхэттене». Автор анализирует недооценку и переоценку через призму категории вежливости, содержанием которой являются коммуникативные стратегии.

Ключевые слова: коммуникативные стратегии, недооценка, переоценка, категория вежливости, речь современных англичан.

\section{Abstract}

The article deals with the communicative strategies of understatement and overstatement in the speech of the characters in the modern novel "Shopaholic Abroad". The author analyzes understatement and overstatement through the category of politeness, the content of which are communicative strategies.

Kew words: communicative strategies, understatement and overstatement, the category of politeness, the speech of modern English people.

В лингвистической литературе проблемой недооценки и переоценки в разное время занимались отечественные и зарубежные ученые: Е.В. Власова, И.В. Гюббенет, Т.А. Ивушкина, Т.В. Ларина, У. Болл, Дж. Майкс, А. Смит, А. Хюблер, Х. Филдинг.

Недооценка и переоценка - это языковые категории, которые намеренно занижают или завышают оценочную реакцию на определенные речевые ситуации с целью поддержания гармоничного, бесконфликтного общения и соблюденияобщепринятых норм в процессе коммуникации [3, с. 216]. Содержанием данных категорий являются стратегии, направленные на достижение определенной коммуникативной цели.

В данной работе мы рассматриваем недооценку и переоценку через категорию вежливости, присущую представителям британской лингвокультуры. Т.В. Ларина отмечает, что коммуникативные стратегии недооценки и переоценки могут рассматриваться как одна из форм речевого этикета [5, с. 87].

Стратегии недооценки, или преуменьшения, являются результатом нежелания коммуникантов категорично выражать свои мысли и позволяют смягчить высказывание. Для создания недооценки англичане в своей речи часто используют наречия степени, детенсификаторы (a little, in some respects, a bit, barely, partly, pretty и др), а также некоторые стилистические средства выразительности (мейозис, литота, эвфемизмы) [2, с. 37].

Стратегии переоценки, или преувеличения, являются маркером позитивной вежливости и направлены на сближение с собеседником [5, с. 119]. Переоценка выражается такими средствами выразительности как гипербола, гиперболическая метаформа, сравнение, a также с помощью наречий и прилагательныхинтенсификаторов (absolutely, very, exceedingly, perfectly, so, too и др) [4, с. 138].

Анализ речи персонажей романа Софи Кинселлы «Шопоголик на Манхэттене» (2012 г.) позволил нам выделить 35 контекстов употребления стратегий недооценки и переоценки. Остановимся на стратегиях недооценки: 
Стратегия вежливого отказа представляет собой этикетную формулу вежливости, которая направлена на смягчение информации, потенциально неприятной для собеседника. В представленном диалоге главная героиня пытается вежливо отказаться от приглашения на неинтересное для нее мероприятие с помощью фразы «I'm afraid not», которая является клише, закрепленным в языке культурной традицией [1, c. 137].

(1)'I was planning to... to visit the Guggenheim this afternoon.' ...'Really?' says Kent, looking disappointed. 'Couldn't it wait until another day? "I'm afraid not,' I say. 'There's a particular exhibit I've been absolutely longing to see since . . . since I was a child of six.' [6, c. $180]$.

(一Я планировала... посетить музей Гуггенхайма сегодня.

-Правда? - разочарованно спрашивает Кент. - Не может ли это подождать?

-Боюсь, что нет, - говорю я, - там сейчас выставлено именно то, что я мечтала увидеть... с шести лет (здесь и далее перевод наш. - Т.В.).

Стратегия критического отношения к себе позволяет проявить сдержанность и устранить из фокуса внимания имеющиеся разногласия в целях сохранения позитивных отношений между коммуникантами. Л.В. Азарова отмечает, что сдержанность и уклончивость являются основой вежливого поведения англичан [1, с. 138]. В данном примере у главной героини возникли некоторые неприятности отчасти по неосторожности ее подруги Сьюзан. Обе девушки принимают вину на себя, реализуя стратегию критического отношения к себе за счет многократного повторения фразы «It's my fault».

(2)(Suzan): 'It's all my fault. I was such a moron!... It's all my stupid fault.' 'Of course it's not!' 'Will you ever forgive me?' 'Will I ever forgive you?'

I stare at her, my face quivering. 'Suze . . . I should be asking you to forgive me! You tried to keep tabs on me. You tried to warn me, but I didn't even bother to call you back... I was just so... stupid, so thoughtless...'

'No you weren't!' [6, c. 264] виновата!

((Сьюзан):- Это я во всем виновата. Я была такой дурой! ... Это я во всем

— Конечно, ты ни в чем не виновата!

— Ты сможешь меня когда-нибудь простить?

— Простить тебя? - Я в изумлении уставилась на нее. - Сьюзи... это я должна просить у тебя прощения! Ты пыталась меня сдержать, ты хотела предупредить, но я даже не удосужилась тебе перезвонить... Я была такой... глупой, такой безмозглой...

— Да нет, что ты!)

Стратегия умолчания по этическим соображениям

(3)'Alicia's going to run the London office?' 'Almost definitely,' says Luke,

Stopping mid sentence. 'Why?' 'But--' 'But what?' says Michael, looking at me with interest. 'Why shouldn't she run the London office? She's bright, ambitious...' 'Oh. Well... no reason,' I say feebly. I can't very well say 'because she's a complete cow' [6, c. 198].

(一 Алисия будет возглавлять лондонский офис?

- Наверняка, - Люк вдруг пристально на меня посмотрел, — а что?

- Но...

— Но что? - Майкл с интересом взглянул на меня, — почему, она не может его возглавить? Она умна, амбициозна...

- Ну... да, так, ничего, - неубедительно отвечаю я. Не могу же я им сказать: «да потому что она жуткая дрянь»).

В данном контексте героиня романа избегает четкого выражения негативных оценочных суждений в отношении Алисии, которую она явно недолюбливает. Стратегия недооценки реализуется с помощью множественных пауз, заполнителя «well». Такой уклончивый ответ позволяет проявить сдержанность и соблюсти 
общепринятые нормы, не позволяющие открыто выражать негатив по отношению к собеседнику или иным лицам.

Перейдем к рассмотрению стратегий переоценки:

Стратегия похвалы направлена на сближение с собеседником и реализуется в виде комплиментов и позитивного внимания. Как справедливо отмечает Дж. Лич, речевые акты, содержащие похвалу, являются вежливыми по природе [7]. Реализуя в речи стратегию похвалы, говорящий стремится показать собеседнику свое внимание и уважение.

(4)'I've just been speaking to some people at HLBC. Apparently you were quite a hit. Very entertaining, they said.'

'Wow!' I say, 'Really? Are you sure?'

'Quite sure. They were saying how charming you

were, and how cultured... [6, c. 185].

(— Я только что говорил с теми людьми с телевидения. Похоже, что они в восторге от тебя. Они сказали, что с тобой очень весело.

-Ух ты! Правда? Ты уверен?

— Разумеется. Они говорили, какая ты очаровательная, какая образованная...)

В данном примере переоценка реализуется с помощью наречий very, quite и синтаксического средства выразительности - анафоры (повторение усилительной вопросительной частицы how...how) и комплиментов charming, cultured.

Стратегия одобрения позволяет выразить позитивное отношение к собеседнику и характеризуется гиперболизированной оценочностью, эмотивностью и оптимизмом. Стратегия одобрения чаще всего реализуется с помощью наречий-интенсификаторов.

(5)'Nothing wrong with a bit of office gossip,' says Michael with a warm smile. 'Keeps the wheels turning.' 'Absolutely!' I say emphatically. 'I couldn't agree

more [6, c. 198].

(- Ничего плохого в офисных сплетнях нет, - тепло улыбаясь, говорит Майкл, — это помогает держать руку на пульсе.

- Разумеется, — поддакиваю я, — не могу с Вами не согласиться).

В этом примере главная героиня подчеркивает то, что она полностью разделяет точку зрения Майкла, делового партнера ее бойфренда. Стратегия одобрения реализуется с помощью наречия-интенсификатора absolutely и фразы couldn't agree more. more!'

(6)'Box Beautiful have sold out of my frames! They just phoned up to order some

'Oh Suze! That's fantastic!' [6, c. 19].

(-Магазин «Красивые коробочки» продал все мои рамки! Мне только что позвонили и заказали еще партию!

- О, Сьюзи, это же просто замечательно!)

В данном примере главная героиня старается поддержать свою подругу Сьюзан, которая недавно начала заниматься производством рамок для фотографий. Для того чтобы продажи рамок росли, Ребекка тайно скупает рамки и при разговоре с подругой всячески старается ее подбодрить и выразить свое восторженное отношение к деятельности Сьюзи. Здесь цель использования стратегии одобрения состоит в демонстрации поддержки, внимания к собеседнику, что способствует сближению коммуникантов. Переоценка в речи выражена с помощью оценочного наречия fantastic и междомедия oh.

\section{Стратегия выражения благодарности:}

Т.В. Ларина отмечает, что характерной особенностью коммуникативного поведения англичан является выражение благодарности, которое свидетельствует о том, что собеседник принимает во внимание интересы партнера по коммуникации. В английском языке благодарность является очень важной лингвистической категорией, 
которая выражает чувство признательности собеседнику в ответ на его действия [5, c.197].

(7)'It's yours to keep, and wear. A gift.'

'Thank you,' says Tarquin. 'I'm . .. very grateful [6, c. 146].

(- Это подарок, носи на здоровье.

— Спасибо, - говорит Таркин, — я... я очень благодарен тебе).

Здесь стратегия благодарности выражена с помощью фиксированной формы thank you и усилена благодаря использованию сочетания «интенсификатор + прилагательное» very grateful, а также наличию паузы для повышения экспрессивности высказывания.

Таким образом, стратегии недооценки и переоценки позволяют проявить сдержанность, скромность, выразить позитивное отношение к собеседнику, а также поддержать бесконфликтное и гармоничное общение, что отражает культурные и национальные особенности британского характера. Анализ стратегий недооценки и переоценки в речи современных англичан показал, что представители британской лингвокультуры достаточно часто реализуют эти языковые категории в целях соблюдения основных принципов вежливости.

$$
* * *
$$

1. Азарова Л.В. Лексические средства выражения некатегоричности высказываний / Л.В. Азарова // Системное описание лексики германских языков. - Л.: Изд-во Ленингр. ун-та, 1985. Вып. 5. С. 137-142.

2. Власова Е.В. Социолингвистический аспект изучения недооценки и переоценки в речи современного англичанина: на материале художественных произведений начала XXI в.: дис. ... канд. филол. наук / Е.В. Власова - Волгоград, 2005. — 170 с.

3. Власова Е.В. Ритуализированные стратегии недооценки и переоценки в речи современных англичан / Е.В. Власова // Известия Волгоградского государственного педагогического университета. — 2020. — №1 (144). — С. 216-220.

4. Власова Е.В. Коммуникативные средства выражения недооценки. Поведенческий аспект / Е. В. Власова. - Текст: непосредственный // Известия Волгоградского государственного педагогического университета. — 2020. — №3 (146). — С. 136-140.

5. Ларина Т. В. Категория вежливости и стиль коммуникации: сопоставление английских и русских лингвокультурных традиций / Т. В. Ларина. - М.: Рукописные памятники Древней Руси, 2009. $-287 \mathrm{c}$.

6. Kinsella Sophie. Shopaholic abroad / Sophie Kinsella. — Random house, 2012. — 349 c.

7. Leech G.N. Principles of Pragmatics / G. N. Leech. — London, NY: Longman, 1983.

\section{Шевченко Е.И., Кривошеева Е.И. \\ Особенности перевода описательной документации по строительству и эксплуатации ветряных электростанций с японского на русский язык}

Тихоокеанский государственный университет

(Россия, Хабаровск)

doi: 10.18411/lj-05-2021-284

\section{Аннотация}

В статье рассматриваются лексические, грамматические и синтаксические особенности текстов по теме строительства и эксплуатации ветряных электростанций на японском языке. Исследуются способы образования терминологии и описываются заимствованные сокращения для обозначения технических деталей и специфики процессов. На материале оригинальной документации, анализируются и предлагаются к использованию наиболее эффективные способы перевода документации в рамках указанной темы с японского на русский язык.

Ключевые слова: ветряная электростанция, перевод, трансформации, японский язык, русский язык. 